\title{
The Role of Management Ownership in Bank Governance:
}

\section{Evidence from Taiwan}

\author{
Ping-Chang Lee ${ }^{1}$ \& Hsin-Hong Kang ${ }^{1}$ \\ ${ }^{1}$ Department of Business Administration, National Cheng Kung University, Tainan City, Taiwan \\ Correspondence: Ping-Chang Lee, Department of Business Administration, National Cheng Kung University, No.1 \\ University Road, Tainan City 701, Taiwan
}

Received: August 12, 2017

Accepted: September 5, $2017 \quad$ Online Published: September 12, 2017

doi:10.5430/afr.v6n4p74

URL: https://doi.org/10.5430/afr.v6n4p74

\begin{abstract}
The purpose of this paper is to investigate the relationships that banks' managerial ownership has with financial performance and firm value. We use a sample of 35 Taiwan domestic banks for the period 2005-2014. In the pooled OLS regression analysis, we find that the banks' performance and market value fall as the level of management ownership rises, supporting the managerial entrenchment hypothesis. Moreover, the results show that when the ratio of managerial ownership pledge increases, then financial performance decreases while firm value increases. We conjecture that the positive effect of managerial ownership pledge on market value may be caused by the price maintenance effect of stock pledges. In addition, the evidence shows that there is a higher nonperforming loan ratio in family-dominated banks, and this hints that their loan decisions may have more severe agency problems relative to non-family ones.
\end{abstract}

Keywords: Bank, Management ownership, Stock pledge, Agency problem, Entrenchment hypothesis

\section{Introduction}

The separation of ownership and control is a norm of modern enterprises around the world. Agency theory indicates that managers may fail to act in ways that maximize shareholder wealth. However, given the fact that most managers are often also shareholders of the companies they run, ownership and control are not as separate as is often supposed, and the agency problem has now become a conflict between management shareholders (or controlling shareholders) and non-management shareholders (Shleifer and Vishny 1997; Claessens et al. 2000; Demsetz 1983).

In general, it is widely accepted that if management shareholders hold relatively less ownership, the possibility of agency problems will be greater. As such, the convergence-of-interests hypothesis proposes that increasing the level of managerial ownership can mitigate this potential agency problem (Jensen and Meckling 1976). In contrast, the entrenchment hypothesis suggests that greater managerial ownership may decrease firm performance when the manager has sufficient voting power to more fully control the company (Demsetz 1983; Fama and Jensen 1983). Overall, the relationship between management ownership and firm performance is thus mixed in the existing literature.

The 2008 financial crisis caused that considerable loss around the world. A vast body of literature shows that crisis periods affect the behavior of shareholders, and can lead to agency problems, especially in financial firms (see for example Johnson et al. 2000; Friedman et al. 2003; Saghi-Zedek and Tarazi 2015). Moreover, we find that Taiwanese banks have quite high financial leverage, with Table 1 showing that the average equity multiplier for the banking sector is 6.74 to 8.30 times greater than that seen for non-financial companies over the observed years. Similarly, we can also see high equity multipliers in the banking sectors of other countries, with able 2 presenting data covering 17 OECD countries, with an average equity multiplier of 11.70 in 2016 . Additionally, it is clear that bank's businesses are highly correlated with their cash holdings. A high degree of leverage means that the bank's shareholders and depositors must endure greater risk, while bank products that are highly correlated with cash may be more likely to create more agency problems. 
Table 1 . The average equity multiplier seen in the banking and non-financial sectors

\begin{tabular}{llllll}
\hline & \multicolumn{2}{l}{ The banking industry } & \multicolumn{2}{l}{ Non-financial industries } & \multirow{2}{*}{ AEM $_{B} /$ AEM $_{N}$} \\
\cline { 2 - 5 } & $A E M_{B}$ & observations & $A E M_{N}$ & observations & \\
\hline 2005 & 16.15 & 31 & 1.98 & 755 & 8.15 \\
2006 & 16.06 & 32 & 1.94 & 771 & 8.30 \\
2007 & 15.34 & 33 & 1.92 & 793 & 8.00 \\
2008 & 16.65 & 33 & 2.02 & 818 & 8.24 \\
2009 & 16.29 & 33 & 1.97 & 827 & 8.27 \\
2010 & 16.05 & 34 & 2.06 & 843 & 7.79 \\
2011 & 16.09 & 34 & 2.18 & 850 & 7.40 \\
2012 & 15.12 & 35 & 2.22 & 852 & 6.80 \\
2013 & 15.05 & 35 & 2.20 & 854 & 6.85 \\
2014 & 14.60 & 35 & 2.15 & 854 & 6.74 \\
\hline
\end{tabular}

Note: The AEM represents the average equity multiplier of the industry, and the equity multiplier is calculated by dividing total assets by the total equity.

Table 2. The average equity multiplier of banking for 17 OECD countries in 2016

\begin{tabular}{ll}
\hline Countries & Equity multiplier \\
\hline Canada & 4.83 \\
Australia & 5.29 \\
United States & 6.30 \\
Sweden & 7.54 \\
Slovenia & 8.64 \\
Hungary & 8.71 \\
Poland & 9.71 \\
Norway & 10.11 \\
Spain & 10.89 \\
Chile & 11.08 \\
Belgium & 12.23 \\
Denmark & 12.51 \\
Portugal & 13.63 \\
Finland & 14.90 \\
Korea & 17.97 \\
Netherlands & 19.64 \\
Greece & 24.92 \\
Average & 11.70 \\
\hline
\end{tabular}

Source: The Organization for Economic Co-operation and Development

On the other hand, sometimes management shareholders may pledge their ownership to fill private funding gaps. If so, this indicates that they may face greater financial risk. In particular, when such funds are used to carry out a pyramid or cross-shareholding strategy, then this will make management shareholders' real equity ownership much lower than their level of control would suggest, and this may cause more agency problems (Chen et al. 2007; Chan et al. 2013). In this paper, we will examine the impact of managerial ownership pledges on bank performance and market value. To the best of our knowledge, previous studies have rarely focused on this issue, especially in the banking sector, and thus our work can contribute to the literature and address the current gaps with regard to this 
topic.

Most prior studies use ROA or Tobin's Q to measure corporate performance or value (e.g., Morck et al. 1988; Agrawal and Knoeber 1996; McConnell and Servaes 1990). However, we know that banks rely on borrowers to regularly repay their loans as a main source of revenue. It is thus clear that a higher nonperforming loan ratio (NPLR) shows a bank has worse performance, even if it has the same ROA as other banks. Simultaneously, a higher NPLR also implies that the management has a greater possibility of agency problems. For example, a bank manager may enhance their private interest (in terms of a career move or in the form of kickbacks) by making a loan commitment to a specific individual or company, even if this loan has a high default risk. Therefore, in addition to ROA, this paper also uses NPLR as a proxy to measure the agency problem of banks.

This work mainly investigates three issues: (1) Does management ownership affect a bank's financial performance, nonperforming loan ratio, and market value? (2) Does the ratio of management ownership pledge affect a bank's financial performance, nonperforming loan ratio, and market value? (3) Does being a family-dominated affect a bank's financial performance, nonperforming loan ratio, and market value?

The rest of the article is organized as follows. Section 2 reviews the related literature and proposes research hypotheses. The sample and estimation methods are presented in section 3. Section 4 analyses the empirical results, and Section 5 then concludes this work.

\section{Literature Review}

\subsection{Management Ownership and Firm Performance}

The separation of ownership and control and asymmetric information causes agency conflicts between managers and owners, especially as management shareholders have less equity ownership. Jensen and Meckling (1976) propose the convergence-of-interests hypothesis and argue that increasing the level of managerial ownership can mitigate potential agency problems. In the banking sector, for example, Westman (2011) examines a sample of listed and unlisted banks from 37 different European countries, and also finds that management and board ownership have positive impacts on profitability.

In contrast, the entrenchment hypothesis suggests that management ownership has have a negative impact on firm value when the managerial equity reaches a substantial proportion, with enough voting power to ensure that the manager's private position inside the firm is secure (Demsetz 1983; Fama and Jensen 1983; Weisbach 1988). Farinha (2003) uses a large sample of UK companies and two distinct periods to analyze the entrenchment hypothesis. The results strongly suggest the possibility of managerial entrenchment when insider ownership reaches a threshold of around 30\%. In addition, Griffith et al. (2002) employ a sample of the 100 largest U.S. bank holding companies from 1995 to 1999 to investigate the relation between managerial ownership and financial performance, as measured by market-value-added (MVA) and Tobin's Q. Their results show that there is a significant and negative relation between managerial ownership and performance in commercial banks. They further suggest that managerial entrenchment may offset the positive effects of the convergence-of-interest hypothesis.

Furthermore, Morck et al. (1988) find that there is a nonlinear relationship between management ownership and firm value (as measured by Tobin's Q) in a cross-section sample of 371 Fortune 500 firms with data for 1980. The evidence shows that firm value first increases as board ownership rises to 5\%, then declines as board ownership increases from $5 \%$ to $25 \%$, and finally rises slightly as it goes beyond $25 \%$.

Based on a review of literature, in order to examine the role of management ownership in Taiwan's banking sector, we formulated the following null hypotheses (H0):

Hypothesis 1a: A bank's management ownership does not influence its financial performance.

Hypothesis 1b: A bank's management ownership does not influence on the quality of its loan decisions.

Hypothesis 1c: A bank's management ownership does not influence its market value.

\subsection{Management Ownership Pledge}

Chen and $\mathrm{Hu}$ (2001) indicate that the share pledged loans of management shareholders have a negative impact on

firm performance, because these may provide an incentive for managerial shareholders to invest in riskier projects. Chen et al. (2007) further indicate that if a share pledged loan is for management shareholder's personal use, it may bring cause agency problems, such as earnings management and stock manipulation. In addition, Chan et al. (2013) indicate that when the market value of the pledged stocks falls below the maintenance requirement, margin call pressure often leads management shareholders to implement a repurchase policy to protect their control rights. We 
consider that management shareholders' private leverage may influence bank's performance and market value, as stated in the following null hypotheses (H0):

Hypothesis 2a: Increasing management ownership pledge does not influence bank's financial performance.

Hypothesis 2b: Increasing management ownership pledge does not influence the quality of the bank's loan decisions.

Hypothesis 2c: Increasing management ownership pledge does not influence the bank's market value.

\subsection{Board Size}

A larger board size generally brings more human capital (e.g. knowledge and experience) and contributes to better management, monitoring, and performance. However, too many board members may also cause inefficiency in decision-making, and thus have an adverse impact on performance and market value. For example, Yermack (1996) investigates the relationship between board size and firm value in a sample of 452 large U.S. industrial companies between 1984 and 1991. The results show that board size has a negative impact on firm value, and so indicate that small boards of directors are more effective. Likewise, Guest (2009) uses a large sample of 2,746 UK listed firms over period 1981-2002 to examine the relation between board size and firm performance. The results show that board size has a significantly negative impact on profitability, Tobin's Q and share returns. In addition, Ahmad, Guohui, Hassan, Naseem, and ur Rehman (2016) find that board size has positive effects on a bank's non-performing loans. Moreover, Andres (2008) uses a sample of large international commercial banks from six OECD countries (Canada, France, the UK, Italy, Spain, and the US) to investigate the role of boards of directors, and finds an inverted U-shaped relationship between board size and bank performance. The study concludes by suggesting that the optimal member of directors is around 19.

\subsection{Large Shareholders' Ownership}

According to the efficient monitoring hypothesis, larger shareholders have a greater incentive and cost advantage with regard to supervising managers relative to minority shareholders, and thus can better mitigate owner-manager agency conflicts (Pound 1988). Numerous studies also indicate that multiple large shareholders are an effective corporate governance mechanism, and hence have a positive effect on firm performance (e.g., Maury and Pajuste 2005; Attig et al. 2009; Attig et al. 2013; Boubaker et al. 2016; Zeckhauser and Pound 1990). However, Andres (2008) uses panel data on 275 German exchange-listed companies to investigate the relationship between large shareholders and firm performance. The results show that large ownership has a negative or unmeasurable influence on firm performance. Thomsen et al. (2006) also find that blockholder equity ownership has a negative impact on firm value and accounting profits in continental Europe.

\subsection{Family-dominated}

Several studies suggest that family firms tend to have better firm performance than nonfamily ones (Amit and Villalonga 2014; Anderson and Reeb 2003; Andres 2008; Faccio and Lang 2002; Villalonga and Amit 2006; Maury 2006; Barontini and Caprio 2006). The main argument is that family-dominated firms can reduce the conflict of interest between the owners and managers. However, Adiguzel (2013) finds that family ownership reduces the monitoring effectiveness of independent boards. Moreover, Feldman et al. (2016) indicate that because family firms may pursue multiple objectives in addition to, or other than, the maximization of shareholder value, they may fail to exploit all the available favorable opportunities, and so do not outperform nonfamily firms ( e.g., Miller et al. 2007; Filatotchev et al. 2005; Holderness and Sheehan 1988; Zhou 2012).

We argue that family control of a bank may impact its financial performance, loan-decision quality and market value, as stated in the following null hypotheses (H0):

Hypothesis 3a: Family control of a bank does not influence its financial performance.

Hypothesis 3b: Family control of a bank does not influence its loan decisions quality.

Hypothesis 3c: Family control of a bank does not influence its market value.

\subsection{Government-dominated}

It is generally believed that state-owned enterprises (SOEs) are more inefficient because they have less incentive to control costs, and hence have higher average costs of production than necessary. In the banking sector, for example, several studies report that state-owned banks underperform private ones, especially in developing countries (see Berger et al. 2005; Boubakri et al. 2005; Lin and Zhang 2009; Micco et al. 2007). However, Stiglitz (1993) argues that SOEs are needed to assist in achieving certain government policies (e.g. promoting economic development and 
improving social welfare), which are usually unrelated to firm performance. Shen et al. (2014) indicate that the underperformance of government banks is thus due to political factors. If we remove the role of the government, however, the evidence shows that there is no difference in performance between government and private banks.

\section{Empirical Method}

\subsection{Data Description}

In 2002 and 2004, the Taiwanese government implemented two rounds of financial reform. The main aim of these reforms was to improve domestic banks' capital structures and international competitiveness. Figure 1 presents the trend of return on assets (ROA) and nonperforming loan ratio (NPLR) for Taiwanese domestic banks that underwent the two rounds of financial reform. Accordingly, we use the unbalanced panel data of 35 Taiwan domestic banks from 2005 to 2014 to investigate the role of management ownership in the banking sector (Note 1). Our empirical data is provided by the Taiwan Economic Journal Database (TEJ) and Banking Bureau of Financial Supervisory Commission, R.O.C., which also covers 16 banks that in terms of the tier one capital are ranked within the top 500 in the world(Note 2).

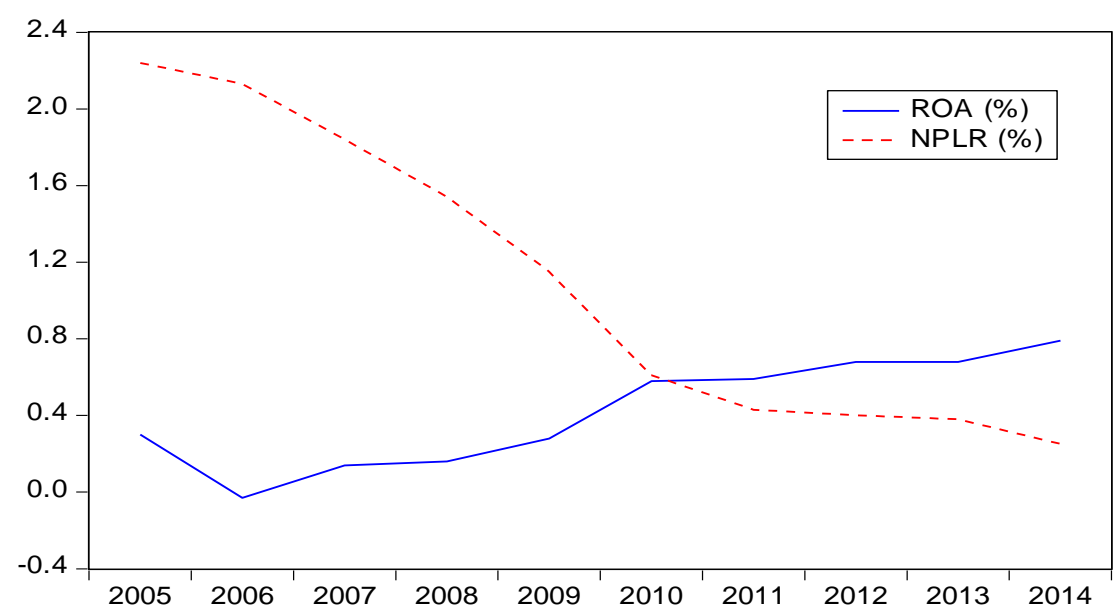

Figure 1. The average ROA and NPLR of Taiwan banking industry

\subsection{Regression Model}

This study aims to investigate the relationships that a bank's management ownership and management ownership pledge loans have with its performance, nonperforming loans, and market value. We use a pooled OLS regression model and develop three dependent variables, ROA, NPLR, and MV, to implement each regression analysis. Our baseline regression model is constructed as follows.

$$
\begin{aligned}
& R O A_{i, t}=\alpha_{0}+\alpha_{1} \operatorname{SIZE}_{i, t}+\alpha_{2} \text { EQUITY }_{i, t}+\alpha_{3} \text { GDP }_{i, t}+\alpha_{4} \text { MO }_{i, t}+\alpha_{5} \text { MOS }_{i, t}+\alpha_{6} \text { LSO }_{i, t}+\alpha_{7} \text { BSIZE }_{i, t} \\
& +\alpha_{8} \text { FAMILY }_{i, t}+\alpha_{9} \text { GOVERN }_{i, t}+\varepsilon_{i, t} \\
& N P L R_{i, t}=\beta_{0}+\beta_{1} S_{I Z E_{i, t}}+\beta_{2} E \operatorname{SUITY}_{i, t}+\beta_{3} G D P_{i, t}+\beta_{4} M O_{i, t}+\beta_{5} M_{0} S_{i, t}+\beta_{6} L S O_{i, t}+\beta_{7} \text { BSIZE }_{i, t} \\
& +\beta_{8} \text { FAMILY }_{i, t}+\beta_{9} \text { GOVERN }_{i, t}+u_{i, t} \\
& M V_{i, t}=\gamma_{0}+\gamma_{1} \text { SIZE }_{i, t}+\gamma_{2} E_{\text {QUITY }}{ }_{i, t}+\gamma_{3} G D P_{i, t}+\gamma_{4} \text { MO }_{i, t}+\gamma_{5} \text { MOS }_{i, t}+\gamma_{6} \text { LSO }_{i, t}+\gamma_{7} \text { BSIZE }_{i, t} \\
& +\gamma_{8} F_{A M I L Y_{i, t}}+\gamma_{9} G_{\text {OVERN }}, t+v_{i, t}
\end{aligned}
$$

where $i$ is the index of the bank, $t$ is the index of the time period, $\varepsilon_{i, t}$ is the error term, and all the variables are defined and presented in Table 3 . 
Table 3. Variable definitions

\begin{tabular}{|c|c|}
\hline Variable & Definition \\
\hline \multicolumn{2}{|c|}{ Dependent variables } \\
\hline$R O A_{i, t}$ & $\begin{array}{l}=\text { The return on assets ratio, which is calculated by dividing net income by average total } \\
\text { assets. }\end{array}$ \\
\hline$N P L R_{i, t}$ & $=$ The bank's nonperforming loans to total gross loans. \\
\hline$M V_{i, t}$ & $\begin{array}{l}=\text { The natural logarithm of the bank's market value, which is obtained by multiplying the } \\
\text { number of its outstanding shares by the year-end share price. }\end{array}$ \\
\hline \multicolumn{2}{|c|}{ Independent variables } \\
\hline$S I Z E_{i, t}$ & $=$ The natural logarithm of total assets. \\
\hline$E Q U I T Y_{i, t}$ & $=$ The equity ratio is calculated by dividing total equity by total assets. \\
\hline$G D P_{i, t}$ & $=$ The growth rate of gross domestic product. \\
\hline$M O_{i, t}$ & $=$ The shareholding ratio of directors and supervisors. \\
\hline $\operatorname{MOS}_{i, t}$ & $=$ The share pledge ratio of directors and supervisors \\
\hline$L S O_{i, t}$ & $=$ A shareholder who's direct and indirect voting rights sum to $10 \%$ or more of the total. \\
\hline$B S I Z E_{i, t}$ & $=$ The number of directors and supervisors. \\
\hline$F A M I L Y_{i, t}$ & $=1$, if a bank is dominated by a family, and zero otherwise. \\
\hline $\operatorname{GOVERN}_{i, t}$ & $=1$, if a bank is dominated by the government, and zero otherwise. \\
\hline
\end{tabular}

Table 4 provides descriptive statistics for the variables in our sample. The data set comprises 315 firm-year observations from 35 banks covering the period from 2005 to 2014, and all the variables are defined as in Table 3.

Table 4. Descriptive statistics

\begin{tabular}{lllllll}
\hline & Mean & Median & Maximum & Minimum & SD & Observations \\
\hline ROA & 0.323 & 0.440 & 5.410 & -7.880 & 1.298 & 315 \\
MV & 11.046 & 11.285 & 13.432 & 8.380 & 250.063 & 315 \\
NPLR & 1.161 & 0.790 & 7.640 & 0.000 & 1.096 & 315 \\
SIZE & 13.238 & 13.110 & 15.298 & 10.615 & 1.087 & 315 \\
EQUITY & 7.965 & 6.090 & 64.710 & 2.820 & 7.653 & 315 \\
GDP & 3.353 & 3.700 & 8.930 & -1.910 & 3.177 & 315 \\
MO & 26.453 & 14.320 & 100.000 & 0.000 & 29.952 & 315 \\
MOP & 19.622 & 0.100 & 100.000 & 0.000 & 29.572 & 315 \\
LSO & 19.170 & 16.990 & 86.340 & 0.000 & 13.982 & 315 \\
BSIZE & 15.254 & 15.000 & 26.000 & 6.000 & 4.505 & 315 \\
FAMILY & 0.610 & 1.000 & 1.000 & 0.000 & 0.489 & 315 \\
GOVERN & 0.159 & 0.000 & 1.000 & 0.000 & 0.366 & 315 \\
\hline
\end{tabular}

The correlation coefficient measures the strength and direction of a linear relationship between two variables. Table 5 presents the correlation analysis results, which can be used to better understand the relations among the independent variables. We find that the correlation coefficients between all independent variables are less than 0.591. 
Table 5. The correlations among the independent variables

\begin{tabular}{|c|c|c|c|c|c|c|c|c|}
\hline $\begin{array}{l}\text { Correlation } \\
\text { (t-Statistic) }\end{array}$ & SIZE & EQUITY & GDP & MO & MOP & LSO & BSIZE & FAMILY GOVERN \\
\hline SIZE & $\begin{array}{l}1.000 \\
(---)\end{array}$ & & & & & & & \\
\hline EQUITY & $\begin{array}{l}-0.222 * * * \\
(-4.027)\end{array}$ & $\begin{array}{l}1.000 \\
(---)\end{array}$ & & & & & & \\
\hline GDP & $\begin{array}{l}0.029 \\
(0.517)\end{array}$ & $\begin{array}{l}0.004 \\
(0.079)\end{array}$ & $\begin{array}{l}1.000 \\
(---)\end{array}$ & & & & & \\
\hline MO & $\begin{array}{l}0.339 * * * \\
(6.384)\end{array}$ & $\begin{array}{l}-0.113 * * \\
(-2.021)\end{array}$ & $\begin{array}{l}0.017 \\
(0.293)\end{array}$ & $\begin{array}{l}1.000 \\
(---)\end{array}$ & & & & \\
\hline MOP & $\begin{array}{l}-0.138 * * \\
(-2.473)\end{array}$ & $\begin{array}{l}0.174 * * * \\
(3.120)\end{array}$ & $\begin{array}{l}-0.033 \\
(-0.593)\end{array}$ & $\begin{array}{l}-0.239 * * * \\
(-4.364)\end{array}$ & $\begin{array}{l}1.000 \\
(---)\end{array}$ & & & \\
\hline LSO & $\begin{array}{l}-0.327 * * * \\
(-6.131)\end{array}$ & $\begin{array}{l}0.092 \\
(1.627)\end{array}$ & $\begin{array}{l}-0.030 \\
(-0.535)\end{array}$ & $\begin{array}{l}-0.546 * * * \\
(-11.540)\end{array}$ & $\begin{array}{l}0.125 * * \\
(2.233)\end{array}$ & $\begin{array}{l}1.000 \\
(---)\end{array}$ & & \\
\hline BSIZE & $\begin{array}{l}0.032 \\
(0.559)\end{array}$ & $\begin{array}{l}0.029 \\
(0.522)\end{array}$ & $\begin{array}{l}-0.018 \\
(-0.312)\end{array}$ & $\begin{array}{l}0.011 \\
(0.186)\end{array}$ & $\begin{array}{l}-0.162 * * * \\
(-2.909)\end{array}$ & $\begin{array}{l}-0.224 * * * \\
(-4.063)\end{array}$ & $\begin{array}{l}1.000 \\
(---)\end{array}$ & \\
\hline FAMILY & $\begin{array}{l}-0.331 * * * \\
(-6.206)\end{array}$ & $\begin{array}{l}0.157 * * * \\
(2.815)\end{array}$ & $\begin{array}{l}0.007 \\
(0.127)\end{array}$ & $\begin{array}{l}-0.591 * * * \\
(-12.959)\end{array}$ & $\begin{array}{l}0.106 * \\
(1.886)\end{array}$ & $\begin{array}{l}0.251 * * * \\
(4.597)\end{array}$ & $\begin{array}{l}-0.159 * * * \\
(-2.845)\end{array}$ & $\begin{array}{l}1.000 \\
(---)\end{array}$ \\
\hline GOVERN & $\begin{array}{l}0.584 * * * \\
(12.714)\end{array}$ & $\begin{array}{l}-0.128 * * \\
(-2.286)\end{array}$ & $\begin{array}{l}-0.002 \\
(-1.142)\end{array}$ & $\begin{array}{l}0.497 * * * \\
(10.139)\end{array}$ & $\begin{array}{l}-0.288 * * * \\
(-5.330)\end{array}$ & $\begin{array}{l}-0.394 * * * \\
(-7.575)\end{array}$ & $\begin{array}{l}0.346 * * * \\
(6.530)\end{array}$ & $\begin{array}{ll}-0.543 * * * & 1.000 \\
(-11.431) & (---)\end{array}$ \\
\hline
\end{tabular}

This table presents the relations among the independent variables, with the t-statistics in parentheses below the correlation coefficients. $* * *, * *$, and $*$ denote statistical significance at the $1 \%, 5 \%$, and $10 \%$ levels, respectively.

\section{Results and Discussion}

\subsection{Empirical Results}

First, Table 6 reports the estimated regression results of equation (1). Our results show that SIZE $(c=0.272, p<0.01)$, EQUITY ( $c=0.075, \mathrm{p}<0.01)$, and GDP $(\mathrm{c}=0.044, \mathrm{p}<0.05)$ have a statistically significant and positive relation with ROA. In addition, MO ( $c=-0.007, \mathrm{p}<0.05)$, MOP ( $\mathrm{c}=-0.005, \mathrm{p}<0.05)$, and LSO ( $=-0.026, \mathrm{p}<0.01)$ have a significantly negative impact on ROA. Moreover, BSIZE, FAMILY, and GOVERN do not have a statistically significant relationship with ROA.

Table 6. The regression results for equation (1) (dependent variable: ROA)

\begin{tabular}{|c|c|c|c|c|}
\hline Variable & Coefficient & Std. Error & t-Statistic & $p$-value \\
\hline $\begin{array}{l}\text { SIZE } \\
\end{array}$ & $0.272 * * *$ & 0.076 & 3.586 & 0.000 \\
\hline EQUITY & $0.075^{* * *}$ & 0.009 & 8.658 & 0.000 \\
\hline GDP & $0.044 * *$ & 0.020 & 2.221 & 0.027 \\
\hline MO & $-0.007 * *$ & 0.003 & -2.030 & 0.043 \\
\hline MOP & $-0.005 * *$ & 0.002 & -2.062 & 0.040 \\
\hline LSO & $-0.026 * * *$ & 0.006 & -4.417 & 0.000 \\
\hline BSIZE & -0.020 & 0.016 & -1.233 & 0.219 \\
\hline FAMILY & 0.122 & 0.179 & 0.682 & 0.496 \\
\hline GOVERN & -0.132 & 0.272 & -0.484 & 0.629 \\
\hline Intercept & $-3.005 * * *$ & 1.144 & -2.626 & 0.009 \\
\hline Adjusted R-squared & 0.253 & & & \\
\hline Observations & 335 & & & \\
\hline
\end{tabular}


Second, Table 7 reports the regression results of equation (2). The results show that SIZE $(c=-0.275, p<0.01)$, EQUITY ( $\mathrm{c}=-0.024, \mathrm{p}<0.01)$, and GDP $(\mathrm{c}=-0.034, \mathrm{p}<0.10)$ have a statistically significant and negative relation with NPLR. In contrast, MO ( $c=0.006, p<0.05)$, MOP $(c=0.005, p<0.05)$, LSO $(c=0.009, p<0.01)$, BSIZE $(0.076$, $\mathrm{p}<0.01)$, and FAMILY $(\mathrm{c}=0.245, \mathrm{p}<0.01)$ have a significantly positive relationship with NPLR. Moreover, there are no statistically significant relations between GOVERN and NPLR.

Table 7. The regression results for equation (2) (dependent variable: NPLR)

\begin{tabular}{lclll}
\hline Variable & Coefficient & Std. Error & t-Statistic & $p$-value \\
\hline SIZE & -0.275 & 0.068 & -4.052 & 0.000 \\
EQUITY & -0.024 & 0.008 & -3.123 & 0.002 \\
GDP & -0.034 & 0.018 & -1.894 & 0.059 \\
MO & 0.006 & 0.003 & 2.164 & 0.031 \\
MOP & 0.005 & 0.002 & 2.332 & 0.020 \\
LSO & 0.009 & 0.005 & 1.648 & 0.100 \\
BSIZE & 0.076 & 0.015 & 5.173 & 0.000 \\
FAMILY & 0.245 & 0.160 & 2.870 & 0.004 \\
GOVERN & -0.050 & 0.243 & -0.207 & 0.836 \\
Intercept & 3.381 & 1.023 & 3.304 & 0.001 \\
Adjusted R-squared & 0.162 & & & \\
Observations & 335 & & & \\
\hline -values are two-tailed $* * * * *$, and $*$ denote statistical significance at the $1 \%, 5 \%$, and $10 \%$ levels, respectively
\end{tabular}

$p$-values are two-tailed. $* * *, * *$, and $*$ denote statistical significance at the $1 \%, 5 \%$, and $10 \%$ levels, respectively

Finally, Table 8 presents the regression results of equation (3). We find that SIZE (c=1.120, p < 0.01), EQUITY $(\mathrm{c}=0.036, \mathrm{p}<0.01)$, GDP $(\mathrm{c}=0.045, \mathrm{p}<0.01)$, MOP $(\mathrm{c}=0.005, \mathrm{p}<0.01)$, and FAMILY $(\mathrm{c}=0.306, \mathrm{p}<0.01)$ have a statistically significant and positive relation with MV. Whereas there is a significantly negative relationship between MO and MV ( $c=-0.007, \mathrm{p}<0.05)$. Moreover, LSO, BSIZE, and GOVERN do not have a statistically significant relationship with MV.

Table 8. The regression results for equation (3) (dependent variable: MV)

\begin{tabular}{lclll}
\hline Variable & Coefficient & Std. Error & t-Statistic & $p$-value \\
\hline SIZE & $1.120^{* * * *}$ & 0.058 & 19.170 & 0.000 \\
EQUITY & $0.036^{* * *}$ & 0.005 & 7.463 & 0.000 \\
GDP & $0.045^{* * *}$ & 0.012 & 3.722 & 0.000 \\
MO & $-0.007^{* *}$ & 0.003 & -2.500 & 0.013 \\
MOP & $0.006^{* * *}$ & 0.001 & 3.903 & 0.000 \\
LSO & 0.001 & 0.004 & 0.030 & 0.976 \\
FAMILY & $0.306^{* * *}$ & 0.115 & 2.664 & 0.008 \\
GOVERN & 0.305 & 0.168 & 1.819 & 0.071 \\
BSIZE & 0.001 & 0.011 & 0.077 & 0.939 \\
Intercept & -4.707 & 0.912 & -5.160 & 0.000 \\
Adjusted R-squared & 0.743 & & & \\
Observations & 213 & & \\
-values are two-tailed. $* * * * *$, and $*$ denote statistical significance at the $1 \%, 5 \%$, and $10 \%$ levels, respectively \\
4.2 Discussion
\end{tabular}

The impact of management ownership on firm performance remains unclear in the existing literature. In the banking sector, the presence of managerial shareholders may create more opportunities for agency problems. Table 9 
combines our main regression results, with the evidence showing that a bank's MO has significantly negative effects on its ROA and MV. This means that a higher management ownership ratio is accompanied by lower financial performance and market value, thus rejecting null hypotheses H1a and H1b. This result also tends to support the managerial entrenchment hypothesis. Moreover, the significant and positive relationship between MO and NPLR also confirms this again, and rejects the null hypothesis H1c.

The agency problem mainly comes from the conflicts of interest that can occur between owners and managers. When a management shareholder increases his private leverage, we consider that he will have a greater incentive to create his private interest from the company. Our evidence indicates that that MOP has a significantly negative influence on ROA, and a positive effect on the bank's NPLR. In other words, a higher pledge ratio of management ownership is associated with worse profitability and a higher nonperforming loan ratio, neither of which are conducive to bank performance. We thus reject the null hypotheses $\mathrm{H} 2 \mathrm{a}$ and $\mathrm{H} 2 \mathrm{~b}$. However, there is a strongly significant and positive relationship between MOP and MV. Chan et al. (2013) argue that in order to protect their control rights and maintain the market value of pledged equity, management shareholders tend to implement a treasury stock policy. We conjecture that the positive relationship between MOP and MV may be the stock price maintenance effect of the management ownership pledge.

Several studies suggest that family firms can relieve the potential conflict of interest between owners and managers, and hence have better firm performance. Our evidence shows that there is no statistically significant relation between FAMILY and ROA, and thus we do not reject the null hypothesis H3a. That said, there is no evidence which shows that being family-dominated will affect a bank's financial performance. However, we find that the family-dominated banks have a significantly higher NPLR, and thus we reject the null hypothesis H3b. This also suggests that such an ownership structure may lead to a higher agency risk with regard to a bank's loan decisions. Moreover, our evidence shows that being dominated by a family has a significantly positive influence on a bank's MV, and this rejects the null hypothesis H3c. Moreover, the evidence also indicates that GOVERN has a positive relationship with MV. This implies that from the perspective of the market, investors have more confidence in state-dominated banks than family-dominated ones.

McAllister and McManus (1993) indicate that larger banks have better risk diversification opportunities and lower funding costs, and thus there is a positive size effect on performance. Because of economies of scale, numerous studies have pointed out that larger banks usually have better performance than smaller ones (e.g., Rangan et al., 1988; Miller and Noulas, 1996; Masood and Ashraf, 2012; Perera et al., 2013). Additionally, Sufian and Chong (2008) indicate that bank profitability is sensitive to macroeconomic conditions, and when there is a decline in economic activity then banking business will shrink, and this will have a negative impact on profitability. Our results show that the assets size (SIZE), equity ratio (EQUITY), and general economic situation (GDP) have significant and positive effects on a bank's ROA and MV. These results are in line with most prior studies.

Additionally, we also find that a higher ratio of large shareholder ownership (LSO) is associated with lower ROA and higher NPLR, and this shows that the large shareholders of banks do not seem to play an effective supervisory role. In addition, the evidence also shows that a larger board size (BSIZE) is accompanied by a higher ratio of nonperforming loans (NPLR), which means that having too many members on a board is likely to harm the quality of loan decisions, and this result is consistent with the findings of Yermack (1996), Eisenberg et al. (1998), Stepanova et al. (2012), and Staikouras et al. (2007). 
Table 9. The main regression results

\begin{tabular}{|c|c|c|c|}
\hline Variable & ROA & NPLR & MV \\
\hline \multirow{2}{*}{ SIZE } & $0.272 * * *$ & $-0.275^{* * *}$ & $1.120 * * *$ \\
\hline & $(3.587)$ & $(-4.052)$ & $(19.170)$ \\
\hline \multirow{2}{*}{ EQUITY } & $0.075 * * *$ & $-0.024 * * *$ & $0.036 * * *$ \\
\hline & $(8.659)$ & $(-3.123)$ & $(7.463)$ \\
\hline \multirow{2}{*}{$G D P$} & $0.044 * *$ & $-0.033^{*}$ & $0.045^{* * *}$ \\
\hline & $(2.221)$ & $(-1.894)$ & $(3.722)$ \\
\hline \multirow{2}{*}{$M O$} & $-0.007 * *$ & $0.006^{* *}$ & $-0.007 * *$ \\
\hline & $(-2.030)$ & $(2.164)$ & $(-2.500)$ \\
\hline \multirow{2}{*}{$M O P$} & $-0.005 * *$ & $0.005^{* *}$ & $0.006 * * *$ \\
\hline & $(-2.062)$ & $(2.332)$ & $(3.903)$ \\
\hline \multirow{2}{*}{ LSO } & $-0.026 * * *$ & $0.009 *$ & 0.001 \\
\hline & $(-4.417)$ & $(1.651)$ & $(0.030)$ \\
\hline \multirow{2}{*}{$B S I Z E$} & -0.020 & $0.076 * * *$ & 0.001 \\
\hline & $(-1.233)$ & $(5.173)$ & $(0.077)$ \\
\hline \multirow{2}{*}{ FAMILY } & 0.122 & $0.461 * * *$ & $0.306 * * *$ \\
\hline & $(0.682)$ & $(2.870)$ & $(2.664)$ \\
\hline \multirow{2}{*}{ GOVERN } & -0.132 & -0.050 & $0.443^{* *}$ \\
\hline & $(-0.484)$ & $(-0.207)$ & $(2.315)$ \\
\hline \multirow{2}{*}{ Intercept } & $-3.005^{* * *}$ & $3.381 * * *$ & $-4.707 * * *$ \\
\hline & $(-2.626)$ & $(3.304)$ & $(-5.160)$ \\
\hline Adjusted R-squared & 0.253 & 0.162 & 0.743 \\
\hline Observations & 335 & 335 & 213 \\
\hline
\end{tabular}

We report the t-statistics in parentheses below the coefficients. ***, **, and * denote statistical significance at the $1 \%, 5 \%$, and $10 \%$ levels, respectively.

\section{Conclusion}

This study investigates the role of management ownership in bank governance. Our results show that a higher management ownership ratio is accompanied by both less bank performance and market value, and this supports the managerial entrenchment hypothesis.

Furthermore, we find that there is a negative relation between management ownership pledge and bank performance. In other words, if management shareholders increase their personal leverage then this is not conducive to a bank's performance. However, we also find that management ownership pledge has a significantly positive relationship with a bank's market value, and we speculate this may be caused by the price maintenance effect of a stock pledge.

Our evidence also shows that being either a family- or government-dominated bank will have a positive impact on market value. In addition, it is worth mentioning that family-dominated banks have a significantly higher nonperforming loan ratio than nonfamily ones, and this implies that they have a greater agency risk in their loan decisions.

It should be noted that generalizability of this study is somewhat limited by the fact that all the data came from Taiwanese banks. However, this paper still contributes to the literature on agency theory as it describes the impact of management shareholders private financial leverage on a bank's performance and market value. To the best of our knowledge, this topic has been neglected in prior studies, and thus our work can contribute to the literature and address this current gap. However, more research is needed to examine the impact of management shareholders' private financial leverage on firm performance and market value in the future in other contexts than the one 
investigated in this study.

\section{References}

Adiguzel, H. (2013). Corporate governance, family ownership and earnings management: emerging market evidence. Accounting and Finance Research, 2(4), 17. https://doi.org/10.5430/afr.v2n4p17

Agrawal, A., \& Knoeber, C. R. (1996). Firm performance and mechanisms to control agency problems between managers and shareholders. Journal of financial and quantitative analysis, 31(3), 377-397. https://doi.org/10.2307/2331397

Ahmad, M. I., Guohui, W., Hassan, M., Naseem, M. A., \& ur Rehman, R. (2016). NPL and Corporate Governance: A Case of Banking Sector of Pakistan. Accounting and Finance Research, 5(2), 32. https://doi.org/10.5430/afr.v5n2p32

Amit, R., \& Villalonga, B. (2014). Financial performance of family firms. The Sage handbook of family business, 157-178. https://doi.org/10.4135/9781446247556.n9

Anderson, R. C., \& Reeb, D. M. (2003). Founding-family ownership and firm performance: evidence from the S\&P 500. The Journal of Finance, 58(3), 1301-1328. https://doi.org/10.1111/1540-6261.00567

Andres, C. (2008). Large shareholders and firm performance-An empirical examination of founding-family ownership. Journal of Corporate Finance, 14(4), 431-445. https://doi.org/10.1016/j.jcorpfin.2008.05.003

Attig, N., El Ghoul, S., \& Guedhami, O. (2009). Do multiple large shareholders play a corporate governance role? Evidence from East Asia. Journal of Financial Research, 32(4), 395-422. https://doi.org/10.1111/j.1475-6803.2009.01255.x

Attig, N., El Ghoul, S., Guedhami, O., \& Rizeanu, S. (2013). The governance role of multiple large shareholders: evidence from the valuation of cash holdings. Journal of Management \& Governance, 17(2), 419-451. https://doi.org/10.1007/s10997-011-9184-3

Barontini, R., \& Caprio, L. (2006). The effect of family control on firm value and performance: Evidence from continental Europe. European Financial Management, 12(5), 689-723. https://doi.org/10.1111/j.1468-036X.2006.00273.x

Berger, A. N., Clarke, G. R., Cull, R., Klapper, L., \& Udell, G. F. (2005). Corporate governance and bank performance: A joint analysis of the static, selection, and dynamic effects of domestic, foreign, and state ownership. Journal of Banking \& Finance, 29(8), 2179-2221. https://doi.org/10.1016/j.jbankfin.2005.03.013

Boubaker, S., Nguyen, P., \& Rouatbi, W. (2016). Multiple Large Shareholders and Corporate Risk-taking: Evidence from French Family Firms. European Financial Management, 22(4), 697-745. https://doi.org/10.1111/eufm.12086

Boubakri, N., Cosset, J.-C., \& Guedhami, O. (2005). Liberalization, corporate governance and the performance of privatized firms in developing countries. Journal of Corporate Finance, 11(5), 767-790. https://doi.org/10.1016/j.jcorpfin.2004.05.001

Chan, K., Chen, H.-K., Hu, S.-y., \& Liu, Y.-J. (2013). Shares pledged and corporate repurchase. Paper presented at the 2013 Financial Management Association Annual Meeting.

Chen, A., Kao, L., \& Chen, Y.-K. (2007). Agency Costs of Controlling Shareholders' Share Collateral with Taiwan Evidence. Review of Pacific Basin Financial Markets and Policies, 10(02), 173-191. https://doi.org/10.1142/S021909150700101X

Chen, Y., \& Hu, S.-Y. (2001). The controlling shareholder's personal stock loan and firm performance.

Claessens, S., Djankov, S., \& Lang, L. H. (2000). The separation of ownership and control in East Asian corporations. Journal of financial Economics, 58(1), 81-112. https://doi.org/10.1016/S0304-405X(00)00067-2

Demsetz, H. (1983). The structure of ownership and the theory of the firm. The Journal of Law and Economics, 26(2), 375-390. https://doi.org/10.1086/467041

Eisenberg, T., Sundgren, S., \& Wells, M. T. (1998). Larger board size and decreasing firm value in small firms. Journal of financial Economics, 48(1), 35-54. https://doi.org/10.1016/S0304-405X(98)00003-8

Faccio, M., \& Lang, L. H. (2002). The ultimate ownership of Western European corporations. Journal of financial Economics, 65(3), 365-395. https://doi.org/10.1016/S0304-405X(02)00146-0 
Fama, E. F., \& Jensen, M. C. (1983). Separation of ownership and control. The Journal of Law and Economics, 26(2), 301-325. https://doi.org/10.1086/467037

Farinha, J. (2003). Dividend policy, corporate governance and the managerial entrenchment hypothesis: an empirical analysis. Journal of Business Finance \& Accounting, $30(9 \quad-\quad 10), \quad 1173-1209$. https://doi.org/10.1111/j.0306-686X.2003.05624.X

Feldman, E. R., Amit, R. R., \& Villalonga, B. (2016). Corporate divestitures and family control. Strategic Management Journal, 37(3), 429-446. https://doi.org/10.1002/smj.2329

Filatotchev, I., Lien, Y.-C., \& Piesse, J. (2005). Corporate governance and performance in publicly listed, family-controlled firms: Evidence from Taiwan. Asia Pacific Journal of Management, 22(3), 257-283. https://doi.org/10.1007/s10490-005-3569-2

Friedman, E., Johnson, S., \& Mitton, T. (2003). Propping and tunneling. Journal of Comparative Economics, 31(4), 732-750. https://doi.org/10.1016/j.jce.2003.08.004

Griffith, J. M., Fogelberg, L., \& Weeks, H. S. (2002). CEO ownership, corporate control, and bank performance. Journal of Economics and Finance, 26(2), 170-183. https://doi.org/10.1007/BF02755984

Guest, P. M. (2009). The impact of board size on firm performance: evidence from the UK. The European Journal of Finance, 15(4), 385-404. http://dx.doi.org/10.1080/13518470802466121

Holderness, C. G., \& Sheehan, D. P. (1988). The role of majority shareholders in publicly held corporations: An exploratory analysis. Journal of financial Economics, 20, 317-346. https://doi.org/10.1016/0304-405X(88)90049-9

Jensen, M. C., \& Meckling, W. H. (1976). Theory of the firm: Managerial behavior, agency costs and ownership structure. Journal of financial Economics, 3(4), 305-360. https://doi.org/10.1016/0304-405X(76)90026-X

Johnson, S., Boone, P., Breach, A., \& Friedman, E. (2000). Corporate governance in the Asian financial crisis. Journal of financial Economics, 58(1), 141-186. https://doi.org/10.1016/S0304-405X(00)00069-6

Lin, X., \& Zhang, Y. (2009). Bank ownership reform and bank performance in China. Journal of Banking \& Finance, 33(1), 20-29. https://doi.org/10.1016/j.jbankfin.2006.11.022

Masood, O., \& Ashraf, M. (2012). Bank-specific and macroeconomic profitability determinants of Islamic banks: The case of different countries. Qualitative Research in Financial Markets, 4(2/3), 255-268. https://doi.org/10.1108/17554171211252565

Maury, B. (2006). Family ownership and firm performance: Empirical evidence from Western European corporations. Journal of Corporate Finance, 12(2), 321-341. https://doi.org/10.1016/j.jcorpfin.2005.02.002

Maury, B., \& Pajuste, A. (2005). Multiple large shareholders and firm value. Journal of Banking \& Finance, 29(7), 1813-1834. https://doi.org/10.1016/j.jbankfin.2004.07.002

McAllister, P. H., \& McManus, D. (1993). Resolving the scale efficiency puzzle in banking. Journal of Banking \& Finance, 17(2-3), 389-405. https://doi.org/10.1016/0378-4266(93)90039-G

McConnell, J. J., \& Servaes, H. (1990). Additional evidence on equity ownership and corporate value. Journal of financial Economics, 27(2), 595-612. https://doi.org/10.1016/0304-405X(90)90069-C

Micco, A., Panizza, U., \& Yanez, M. (2007). Bank ownership and performance. Does politics matter? Journal of Banking \& Finance, 31(1), 219-241. https://doi.org/10.1016/j.jbankfin.2006.02.007

Miller, D., Le Breton-Miller, I., Lester, R. H., \& Cannella, A. A. (2007). Are family firms really superior performers? Journal of Corporate Finance, 13(5), 829-858. https://doi.org/10.1016/j.jcorpfin.2007.03.004

Miller, S. M., \& Noulas, A. G. (1996). The technical efficiency of large bank production. Journal of Banking \& Finance, 20(3), 495-509. https://doi.org/10.1016/0378-4266(95)00017-8

Morck, R., Shleifer, A., \& Vishny, R. W. (1988). Management ownership and market valuation: An empirical analysis. Journal of financial Economics, 20, 293-315. https://doi.org/10.1016/0304-405X(88)90048-7

Pasiouras, F., \& Kosmidou, K. (2007). Factors influencing the profitability of domestic and foreign commercial banks in the European Union. Research in International Business and Finance, 21(2), 222-237. https://doi.org/10.1016/j.ribaf.2006.03.007

Perera, S., Skully, M., \& Chaudhry, Z. (2013). Determinants of commercial bank profitability: South Asian evidence. 
Asian Journal of Finance \& Accounting, 5(1), 365. https://doi.org/10.5296/ajfa.v5i1.3012

Pound, J. (1988). Proxy contests and the efficiency of shareholder oversight. Journal of financial Economics, 20, 237-265. https://doi.org/10.1016/0304-405X(88)90046-3

Rangan, N., Grabowski, R., Aly, H. Y., \& Pasurka, C. (1988). The technical efficiency of US banks. Economics letters, 28(2), 169-175. https://doi.org/10.1016/0165-1765(88)90109-7

Saghi-Zedek, N., \& Tarazi, A. (2015). Excess control rights, financial crisis and bank profitability and risk. Journal of Banking \& Finance, 55, 361-379. https://doi.org/10.1016/j.jbankfin.2014.10.011

Shen, C.-H., Hasan, I., \& Lin, C.-Y. (2014). The government's role in government-owned banks. Journal of Financial Services Research, 45(3), 307-340. https://doi.org/10.1007/s10693-013-0168-0

Shleifer, A., \& Vishny, R. W. (1997). A survey of corporate governance. The Journal of Finance, 52(2), 737-783. https://doi.org/10.1111/j.1540-6261.1997.tb04820.x

Staikouras, P. K., Staikouras, C. K., \& Agoraki, M.-E. K. (2007). The effect of board size and composition on European bank performance. European Journal of Law and Economics, 23(1), 1-27. https://doi.org/10.1007/s10657-007-9001-2

Stepanova, A., Ivantsova, O., Stepanov, S., Vernikov, A., \& Bokov, V. (2012). Role of Corporate Governance in Banking Sector: Evidence from all over the world. Electronic Journal of Corporate Finance, 4(24), 80-86.

Stiglitz, J. E. (1993). The role of the state in financial markets. The World Bank Economic Review, 7(suppl_1), 19-52. https://doi.org/10.1093/wber/7.suppl_1.19

Sufian, F., \& Chong, R. R. (2008). Determinants of bank profitability in a developing economy: empirical evidence from the Philippines. Asian Academy of Management Journal of Accounting \& Finance, 4(2).

Thomsen, S., Pedersen, T., \& Kvist, H. K. (2006). Blockholder ownership: Effects on firm value in market and control based governance systems. Journal of Corporate Finance, 12(2), 246-269. https://doi.org/10.1016/j.jcorpfin.2005.03.001

Villalonga, B., \& Amit, R. (2006). How do family ownership, control and management affect firm value? Journal of financial Economics, 80(2), 385-417. https://doi.org/10.1016/j.jfineco.2004.12.005

Weisbach, M. S. (1988). Outside directors and CEO turnover. Journal of financial Economics, 20, 431-460. https://doi.org/10.1016/0304-405X(88)90053-0

Westman, H. (2011). The impact of management and board ownership on profitability in banks with different strategies. Journal of Banking \& Finance, 35(12), 3300-3318. https://doi.org/10.1016/j.jbankfin.2011.05.013

Yermack, D. (1996). Higher market valuation of companies with a small board of directors. Journal of financial Economics, 40(2), 185-211. https://doi.org/10.1016/0304-405X(95)00844-5

Zeckhauser, R. J., \& Pound, J. (1990). Are large shareholders effective monitors? An investigation of share ownership and corporate performance Asymmetric information, corporate finance, and investment (pp. 149-180): University of Chicago Press.

Zhou, H. (2012). Are family firms better performers during financial crisis? Essays on Family Firms, Copenhagen business school handelshøjskolen, 59-116.

\section{Notes}

Note 1. The total number of domestic banks in Taiwan is 38 in 2014.

Note 2. See the survey July 2015 issue of The Banker. 